\title{
Flexural Retrofitting of R.C Beam Using Hybrid Laminates
}

\author{
Mohamed Asick Umar . $\mathbf{H}^{1}$, Manikandan . $\mathbf{T}^{2}$ \\ ${ }^{1}$ P.G. Student, Department of Civil Engineering, PSNA College of Engineering and Technology, Dindigul, Tamil Nadu, India \\ ${ }^{2}$ Assistant Professor, Department of Civil Engineering, PSNA College of Engineering and Technology, Dindigul, Tamil Nadu, India
}

\begin{abstract}
Reinforced concrete (RC) structure using externally bonded fiber reinforced polymer (FRP) components has become a very worldwide practice, extensively accepted by recent design codes. In particular, the flexural strength of a reinforced concrete beam can be broadly increased by application of carbon, glass FRP sheets adhesively bonded to the tension face of the beam. In this experimental study, a total of nine beam specimens $(1000 \mathrm{~mm} \times 150 \mathrm{~mm} \times 200 \mathrm{~mm})$ of $M 20$ grade concrete are casted and preloaded with $75 \%$ of ultimate load by two point load method, later retrofitted with hybrid laminates (GFRP+CFRP) of different thicknesses at U-wrap bonding technique used to examine the flexural behavior of RC beam.. A comparative study is to be made with the test results.
\end{abstract}

Keywords: Fiber Reinforced Polymer (FRP), carbon,glass, energy absorption capacity, ductility, debonding.

\section{Introduction}

Carbon fiber (CF) and glass fiber (GF) are two materials suitable for strengthening concrete structures (American Concrete Institute2000) CF has a high strength and a high elastic modulus. CF is more expensive and its elongation at fracture is relatively small(1-1.5\%), while GF is cheaper and has a relatively large elongation(3-5.4\%) (ACI 2000). However, the elastic modulus of GF insignificantly lower than that of CF. The ductility and stiffness of CF reinforced polymer (CFRP) strengthened beams are noticeably lower and higher than those of GF reinforced polymer(GFRP) strengthened beams.

In order to use fiber materials more efficiently (to increase the elongation with a slight influence on stiffness) the writers proposed an idea to strengthen reinforced concrete (RC) beams by combining CF and GF sheets. A low weight of the fibre make it easy to handle without lifting equipment at site, negligible change of cross section, self weight and free height of a structure. Based on the chemical composition, properties and their usage glass fibers are classified as chopped strand mat, woven roving, E-glass, S- glass, satin weave cloth and laminate. Glass fibers have temperature resistance and high strength but it is the low cost that makes GFRP the most fashionable FRP reinforcement in civil engineering applications. In the Asian region GFRPs have been found very attractive due to their cost competitiveness over carbon fiber composites. Over past few years, external strengthening using FRP composites gained popularity over steel because of several reasons including material cost, lightweight feature, corrosion free and ease of application. At the same time, widespread experimental, numerical and analytical research has been carried out to understand and model the structural behaviour of FRP strengthened reinforced concrete beams. Particular awareness has been given to recognizing and understanding the failure modes that reinforced concrete beams retrofitted with FRP.

\section{A. Objectives}

The objectives of this study includes

- To investigate the improvement in flexural strength of reinforced concrete beams using HFRP laminates with various thickness.

- To evaluate the mode of failure of beams before and after the strengthening of beams.

\section{B. Methodology}

- Externally Bonded Reinforcing (EBR) technique

Fibre Reinforced Polymer can be effectively used for upgrading and strengthening concrete structures. The FRP sheets are generally applied externally on the surface of the structural element to be strengthened using an adhesive. This is called Externally Bonded Reinforcing (EBR) technique. Epoxy resin is used as adhesive.

\section{Experimental Investigation}

\section{A. Materials}

The composition of the concrete mixes was 0.50:1:1.60:2.93 (water: ordinary Portland cement: sand: stone).The cement used is OPC of 53 Grade. The fine aggregate used is fine sand, which confirms to zone II of IS: 383 - 1970. The coarse aggregate used confirms to IS: 383 - 1970.HFRP sheet is used for flexural strengthening of reinforced concrete beams in this study. Epoxy resin is used to bond HFRP sheet to the concrete. The 28-day concrete strength was $39.7 \mathrm{MPa}$. $10 \mathrm{~mm}$ diameter deformed steel bars were used as the main reinforcement. The yield strength and elastic modulus of the 10-mm diameter bars were $411 \mathrm{MPa}$ and $200 \mathrm{GPa}$, respectively.8-mm diameter steel bars with a yield strength of $233 \mathrm{MPa}$ and an elastic modulus of $210 \mathrm{GPa}$ were used as stirrups. 


\section{International Journal of Science and Research (IJSR) \\ ISSN (Online): 2319-7064 \\ Index Copernicus Value (2013): 6.14 | Impact Factor (2015): 6.391}

Table 1: Qualitative Comparison between Glass, and Carbon Fibres

\begin{tabular}{|c|c|c|}
\hline Criterion & Glass Fibers & Carbon Fibers \\
\hline Compressive Strength & Very Good & Very Good \\
\hline Tensile Strength & Good & Very Good \\
\hline Young's Modulus & Adequate & Very Good \\
\hline Long-Term Behaviour & Adequate & Very Good \\
\hline Fatigue Behaviour & Adequate & Excellent \\
\hline Bulk Density & Adequate & Good \\
\hline Alkaline Resistance & Inadequate & Very good \\
\hline Price & Very good & Adequate \\
\hline
\end{tabular}

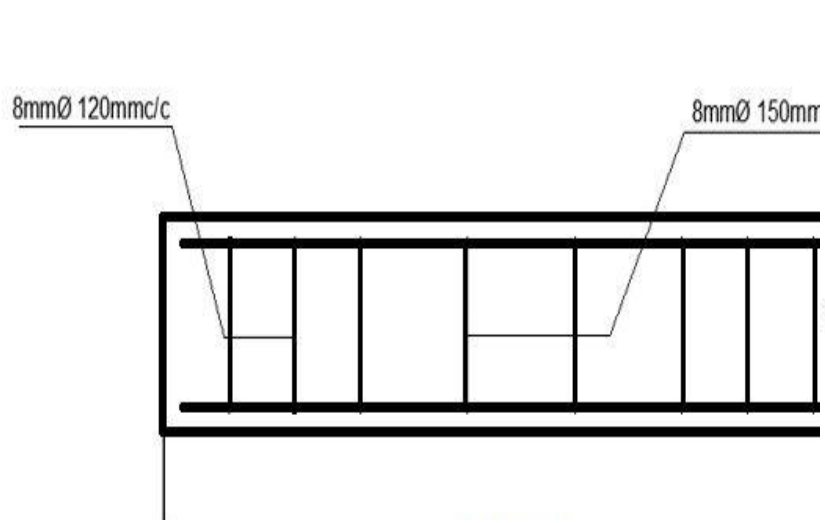

Figure 1: Control specimen reinforcement details

\section{Beam Specimen Details}

A total of 9 beams will be tested in this study. For each type, three specimens are prepared. The specimen details are given in Fig 1.
The bottom tension reinforcement consisted of 3 nos. of deformed steel bars of nominal diameter $10 \mathrm{~mm}$ running along the full length of the beams and 3 nos of the bars were terminated with a 90-degree bent at $100 \mathrm{~mm}$ away from the midspan section on both sides, as shown in Fig. 3. This arrangement of the bottom reinforcement was selected to ensure that the flexural failure of the strengthened beam will always occur at the midspan section. The top compression reinforcement consisted of 2 nos. deformed steel bars of nominal diameter $10 \mathrm{~mm}$. The beams were designed to avoid compression failure due to concrete crushing and shear failure before failure of the strengthening system. Shearreinforcement consisted of double-legged steel stirrupsdeformed steel bar of nominal diameter 8mmuniformly spaced at $120 \mathrm{~mm}$ centre to centre at both ends and $150 \mathrm{~mm}$ centre to centre at the midspan. All of the beams were wet-cured by covering with wet burlap for 28 days and then exposed in an outdoor environment up to one or two days before testing.

Table 2: Specimen details

\begin{tabular}{|c|c|c|}
\hline $\begin{array}{c}\text { No: of } \\
\text { Specimens }\end{array}$ & Specimen designation & $\begin{array}{c}\text { FRP strengthening } \\
\text { system }\end{array}$ \\
\hline 3 & CB & No strengthening \\
\hline 3 & HFRP(3.3mm) & HFRP U-wrap \\
\hline 3 & HFRP(3.6mm) & HFRP U-wrap \\
\hline
\end{tabular}

Note: CB-Control beam, HFRP-Hybrid fibre reinforced polymer

\section{a. Flexural Strengthening}

Two strengthening systems are used:

- Hybrid fiber reinforced polymer (HFRP) in $3.6 \mathrm{~mm}$ thickness. Two layer of GFRP $3 \mathrm{~mm}$ thickness of $80 \%$,two layers of CFRP $0.6 \mathrm{~mm}$ thickness of $20 \%$.

- Hybrid fiber reinforced polymer (HFRP) in3.3 mm thickness. Two layer of GFRP $3 \mathrm{~mm}$ thickness of $90 \%$ ,two layers of CFRP $0.3 \mathrm{~mm}$ thickness of $10 \%$

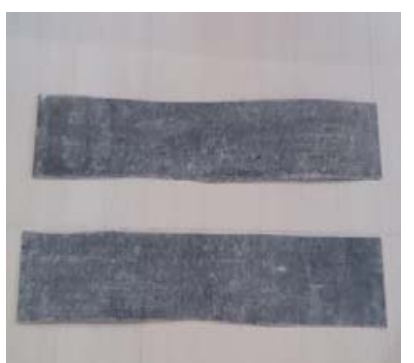

Figure 2: HFRP laminates

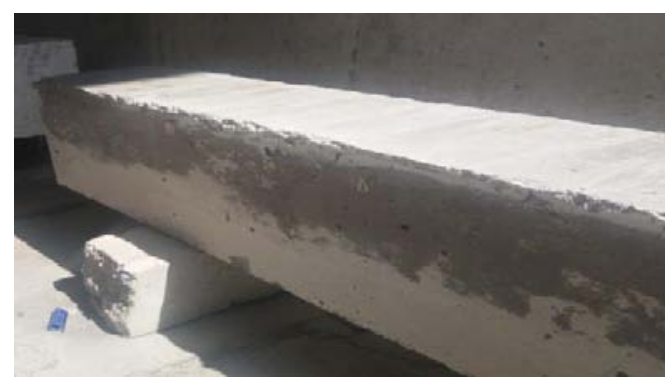

Figure 3: Concrete surface smoothening

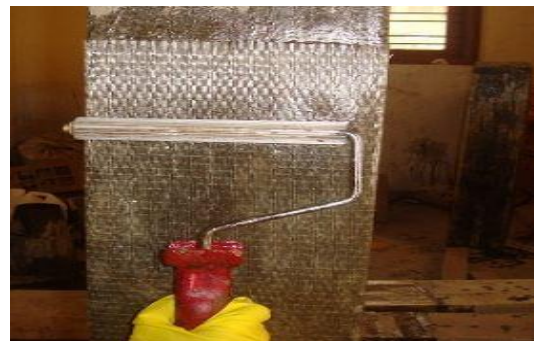

Figure 4: EBR technique

\section{b. Test Procedure}

A total of nine, simply supported, $1 \mathrm{~m}$ long, concrete beams were casted and tested under the Universal Testing Machine (UTM) monotonically increasing concentrated load applied at midspan of the beam. A two- point loading system is 


\section{International Journal of Science and Research (IJSR) \\ ISSN (Online): 2319-7064}

Index Copernicus Value (2013): 6.14 | Impact Factor (2015): 6.391

adopted for this test. An LVDT was kept at the middle of the beam to find the midspan deflection. At the end of each load increment, deflection will be observed. The ultimate load and maximum deflection will be noted for each specimen. The test setup of a control beam specimen is shown in Fig 6 below.

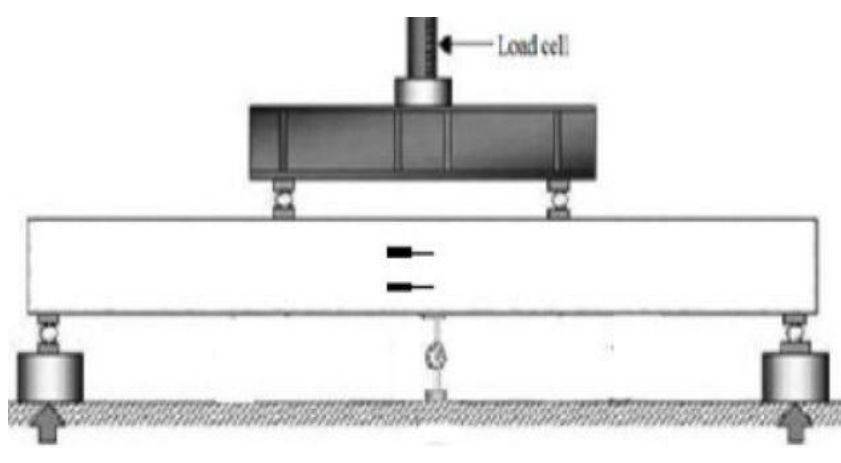

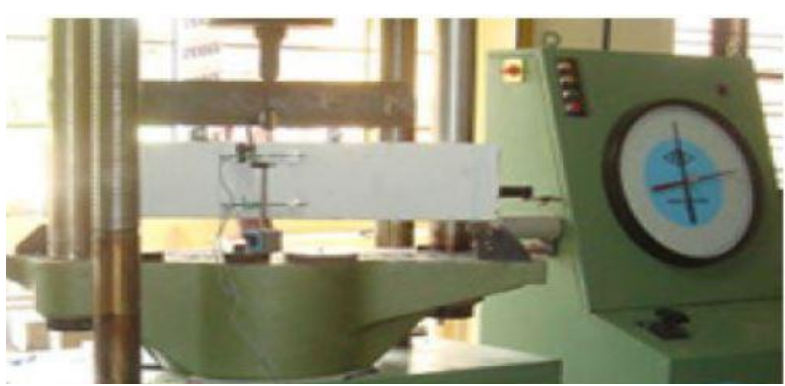

Figure 5: Load test setup

\section{Results and Discussions}

M20 mix was designed as per IS 1026:2009 guidelines. Selected mix proportion is 1: 1.63: 3.04. Total number of beam specimens used in this study is 9 . For each type 3 specimens were tested.The load deflection behaviour of reinforced concrete beams are discussed here. Fig 5 shows the load deflection behaviour of control specimen and the retrofitted beams with HFRP laminates.

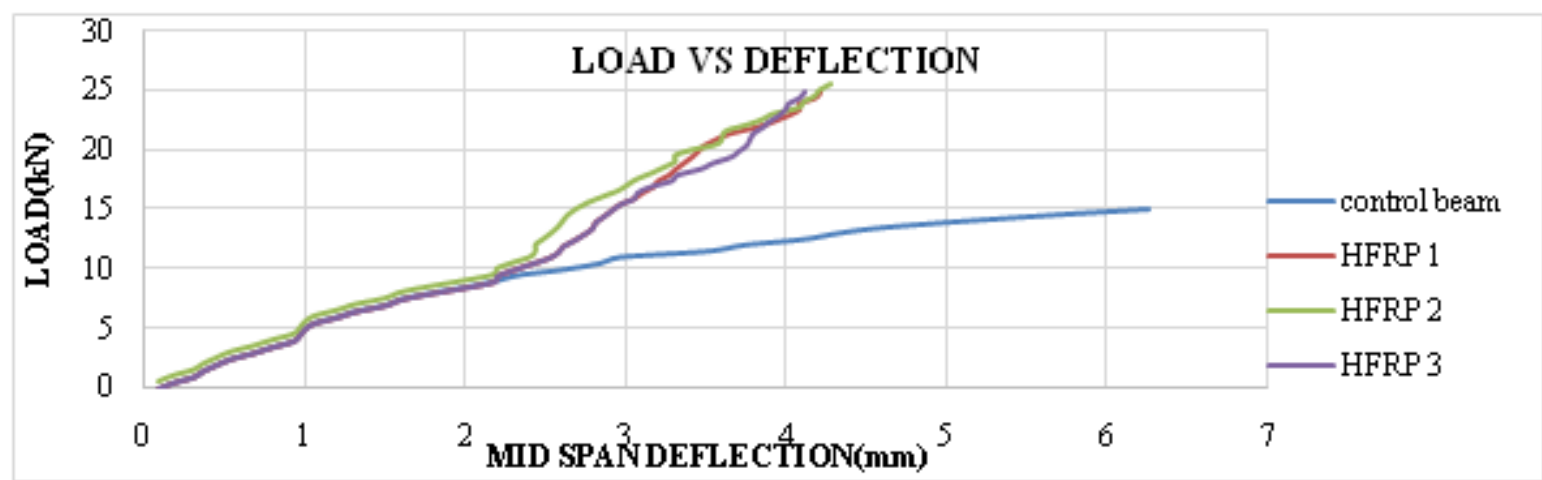

Figure 5: Midspan deflection vs load graph between control and HFRP (3.3mm)

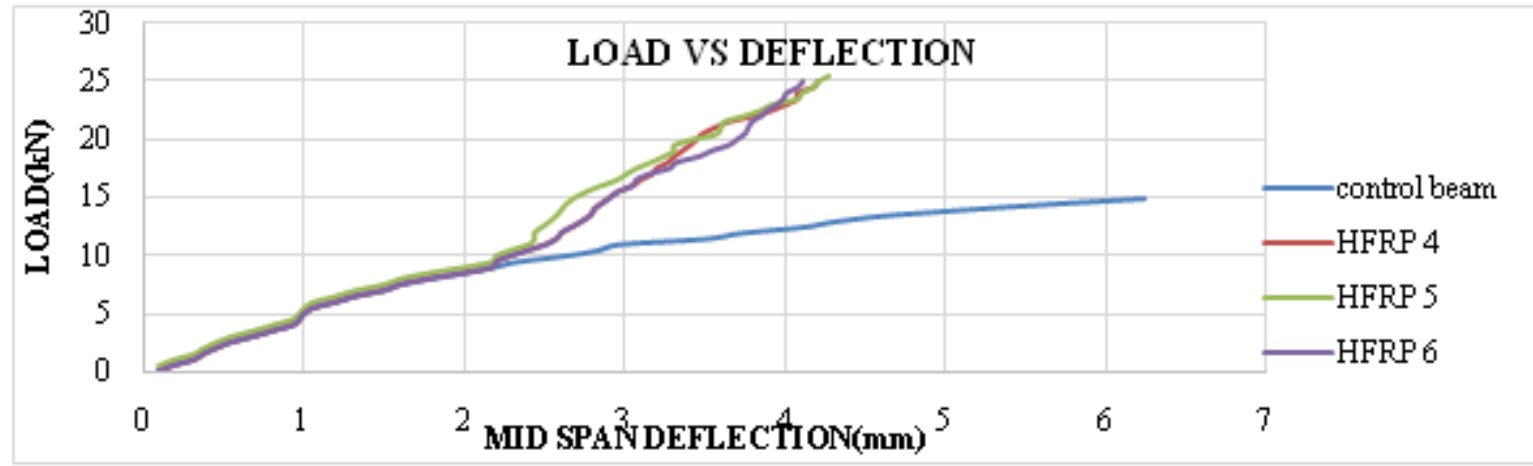

Figure 6: Midspan deflection vs load graph between control and HFRP (3.6 mm)

Table 3: Test result

\begin{tabular}{|c|c|c|c|c|}
\hline $\begin{array}{c}\text { Beam } \\
\text { Designation }\end{array}$ & $\begin{array}{c}\text { First crack } \\
\text { load (kN) }\end{array}$ & $\begin{array}{c}\text { Ultimate } \\
\text { load(kN) }\end{array}$ & $\begin{array}{c}\text { Preload } \\
(\mathrm{kN})\end{array}$ & $\begin{array}{c}\text { \% Increase in } \\
\text { ultimate load }\end{array}$ \\
\hline CB & 5.0 & 15.5 & - & - \\
\hline $\begin{array}{c}\text { HFRP 1 } \\
(3.3 m m)\end{array}$ & 4.6 & 25.73 & 11.5 & 66 \\
\hline $\begin{array}{c}\text { HFRP 2 } \\
(3.3 m m)\end{array}$ & 4.8 & 26.19 & 11.5 & 69 \\
\hline $\begin{array}{c}\text { HFRP 3 } \\
(3.3 m m)\end{array}$ & 4.4 & 25.42 & 11.5 & 64 \\
\hline $\begin{array}{c}\text { HFRP 4 } \\
(3.6 m m)\end{array}$ & 5.0 & 26.66 & 11.5 & 72 \\
\hline $\begin{array}{c}\text { HFRP 5 } \\
(3.6 m m)\end{array}$ & 4.8 & 27.28 & 11.5 & 76 \\
\hline $\begin{array}{c}\text { HFRP 6 } \\
(3.6 m m)\end{array}$ & 4.8 & 27.12 & 11.5 & 75 \\
\hline
\end{tabular}

\subsection{Ultimate Load}

Compared to the conventional reinforced beams, the result shows an increase in the ultimate applied load up to $76 \%$. All beams retrofitted with HFRP laminates $(3.3 \mathrm{~mm})$ exhibit an increase of the ultimate load of $69 \%$ and $76 \%$ for specimens retrofitted with HFRP laminates $(3.6 \mathrm{~mm})$ respectively. The retrofitted beams with HFRP laminates $(3.6 \mathrm{~mm})$ performed at the highest ultimate load $(272 \mathrm{kN})$ compared to those control specimens.

\subsection{Deflection Behaviour}

Figure 5\&6 shows the load-deflection behaviour for conventional reinforced beams and retrofitted beams 


\section{International Journal of Science and Research (IJSR) \\ ISSN (Online): 2319-7064 \\ Index Copernicus Value (2013): 6.14 | Impact Factor (2015): 6.391}

respectively. The result shows that all beams retrofitted with HFRP. Beams were stiffer compared to plain reinforced beams. The ascending part in deflection curves of all beams was analogous to the deflection curve of plain reinforced beams. Nevertheless, the curves of retrofitted beams lay slightly above the path of the deflection curves of the plain reinforced beams. This retrofitting technique has significantly enhanced the strength and increased the ultimate applied load of the preloaded beams and gave better performance than the conventional reinforced beams.

\subsection{Cracking and Failure Mode}

The failure modes of all the beams are shown inFig 6. The cracking and crushing patterns of all beams have been shown, since beams in each category have performed similar cracking and crushing behaviour. All beams were designed to fail in flexure. Shear cracks were noticed in all beams. Some shear cracks remained open and some cracks were small and were closed after the dropping of the load to zero. Flexure and shear cracks in control beam specimens were initiated simultaneously. Only flexure cracks were propagated with the increase of applied loads until failure. The main cracks started to perform near the two point loads, the initiative cracks started to be observed diagonally from the point load toward the bottom of the beam. These cracks were between the point loads and the supports, but closer to the point loads. Then flexure cracks started to perform and propagate in-between and under the two point loads until failure. Prior to failure, crushing on top of the beam at the retrofitted material occurred. Unlike the plain reinforced beams, where shear and flexure cracks initiated simultaneously, the retrofitted material at the bottom section strengthened the beam at the mid span, which delayed the initiation of cracks at the flexural zone until an appropriate applied load had been reached that was adequate to initiate the flexure cracks.

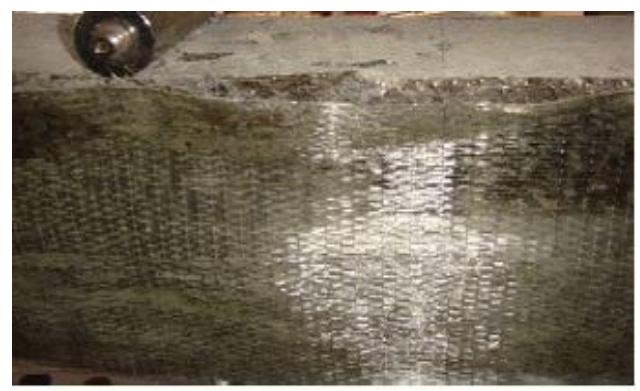

Figure 6: Debonding failure

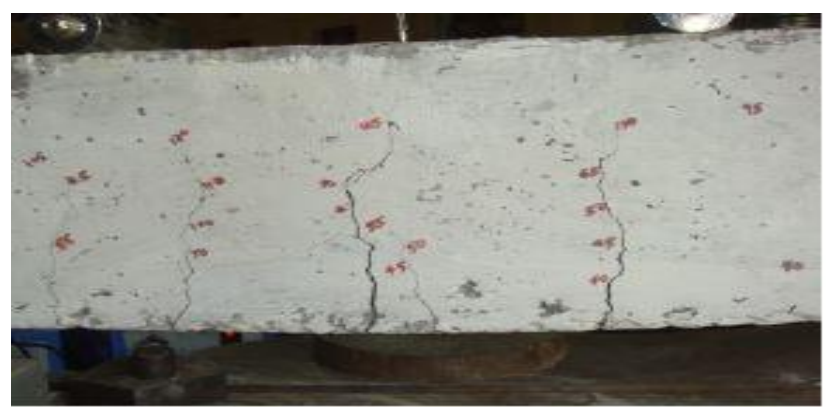

Figure 7: Flexural failure in control beam

\subsection{Energy Absorption and Ductility Factor}

The area under the load deflection curve indicates the energy absorption capacity. The ductility factor is calculated as the ratio of deflection at ultimate load to deflection at yield load.. The energy absorption capacity and ductility factor of various specimens are shown in table 4. Energy absorption capacity and ductility of the strengthened beams are higher compared to control beams.

Table 4: Test result- Flexural strengthening

\begin{tabular}{|c|c|c|}
\hline Beam Designation & $\begin{array}{c}\text { Energy absorption } \\
\text { capacity }(\mathrm{kNm})\end{array}$ & Ductility factor \\
\hline CB & 0.048 & 1.24 \\
\hline $\begin{array}{c}\text { HFRP 1 } \\
(3.3 \mathrm{~mm})\end{array}$ & 0.058 & 1.21 \\
\hline $\begin{array}{c}\text { HFRP 2 } \\
(3.3 \mathrm{~mm})\end{array}$ & 0.059 & 1.18 \\
\hline $\begin{array}{c}\text { HFRP 3 } \\
(3.3 \mathrm{~mm})\end{array}$ & 0.058 & 1.10 \\
\hline $\begin{array}{c}\text { HFRP 4 } \\
(3.6 \mathrm{~mm})\end{array}$ & 0.056 & 1.08 \\
\hline $\begin{array}{c}\text { HFRP 5 } \\
(3.6 \mathrm{~mm})\end{array}$ & 0.067 & 1.05 \\
\hline $\begin{array}{c}\text { HFRP 6 } \\
(3.6 \mathrm{~mm})\end{array}$ & 0.060 & 1.06 \\
\hline
\end{tabular}

\section{Conclusions}

From the study carried out, the following conclusions were been drawn.

- The HFRP laminates(3.6mm) strengthened beams increased the ultimate loads up to $76 \%$ compared to the control beam.

- The HFRP laminates strengthened beams increased the ultimate loads up to $69 \%$ compared to the control beam.

- Due to the higher percentage of carbon fibre in HFRP 5 gave a significant performance on load-deflection behaviour.

- Under similar failure loads the deflection ductility of HFRP(80/20)\% strengthening beams was 13\% lower than that of the HFRP (90/10)\% strengthening beams.

- Prior to failure, flexural cracks were propagated with the increase of load. Subsequently, beams fail in flexural.

\section{References}

[1] Abdelhady hosny, Hamdy Shaheen, Amr Abdelrahman,Tamer Elafandy (2006) "Performance of reinforced concrete beams strengthened by hybrid FRP laminates ${ }^{\text {cee }}$ Journal of concretestructures and materials Vol. (28) .pp. 906-913.

[2] D.kachlakey,D.DMecurry (2000) "Behaviour of full scale reinforced concrete beam retrofitted for shear \& flexural with FRP laminates"Journal of concretestructures and materials Vol. (31) .pp. 445-452.

[3] Murali G. and Pannirselvam N. (2011)"Flexural strengthening of reinforced concrete Beams using fiber reinforced polymer laminate" ARPN Journal of Engineering andApplied Sciences, VOL (6), no. 11, November.

[4] J.Piekarczyk, W. Piekarczyk, S. Blazewicz (2010)"Compression strength of concrete cylinders 


\section{International Journal of Science and Research (IJSR) \\ ISSN (Online): 2319-7064}

Index Copernicus Value (2013): 6.14 | Impact Factor (2015): 6.391

reinforced with carbon fiber laminate"Journal of concretestructures and materials Vol. (26) .pp. 23652369.

[5] Sing-Ping Chiew, Qin Sun; and Yi Yu(2007) „Flexural Strength of RC Beams with GFRP laminates eee Journal of Composites For Construction Vol (11), No. 5, October 1.

[6] G.J.Xiong; J. Z. Yang; and Z. B. Ji (2004)“Behaviour of Reinforced Concrete Beams Strengthened with Externally Bonded Hybrid Carbon Fiber-Glass Fiber Sheets" Journal of Composites For Construction Vol (8), No. 3, June 1.

[7] Yasmeen Taleb Obaidat ,Susanne Heyden , Ola Dahlblom , Ghazi Abu-Farsakh Yahia Abdel-Jawad (2011)"Retrofitting of reinforced concrete beams using composite laminates" Journal of Construction and Building Materials Vol. (25) .pp. 591-597.

[8] T.Manikandan. G.Balajiponraj," Strengthening of RC Beam Using GFRP Wraps", International Journal of Engineering Trends and Technology (IJETT) - Vol.4, Issue5-2013. 